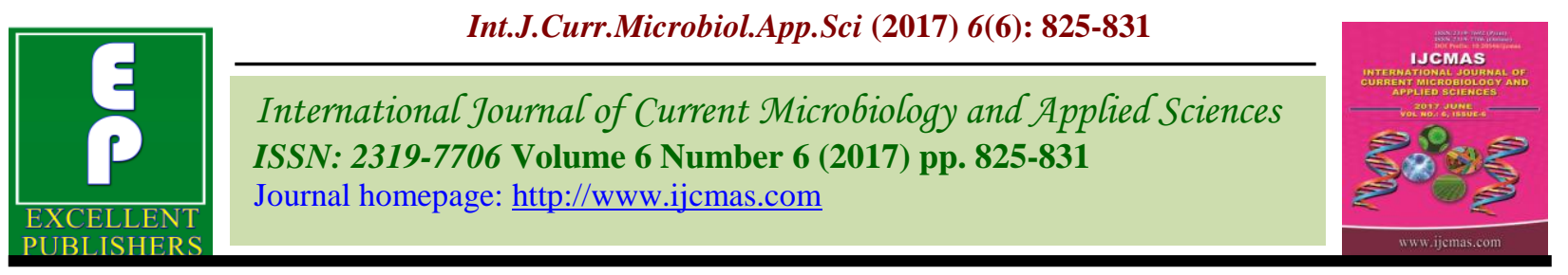

Original Research Article

https://doi.org/10.20546/ijcmas.2017.606.097

\title{
Effect of Sewage Sludge on Marigold (Tagetes erecta)
}

\author{
Praveen Solanki ${ }^{*}$, Bhavya Kalavagadda, Baby Akula, \\ S. Harish Kumar Sharma ${ }^{2}$ and D. Jagdishwar Reddy \\ ${ }^{1}$ Department of Environmental Science and Technology, ${ }^{2}$ Department of Soil Science and \\ Agricultural Chemistry, College of Agriculture, R. Nagar, \\ Acharya N.G. Ranga Agricultural University, Rajendranagar, Hyderabad-500030, India \\ *Corresponding author
}

\section{A B S T R A C T}

\begin{tabular}{|l|}
\hline Ke y w or d s \\
Floriculture, \\
Decorative flower, \\
Waste management, \\
Soil fertility Optical \\
density and \\
Chlorophyll \\
content. \\
\hline Article Info \\
\hline $\begin{array}{l}\text { Accepted: } \\
\text { 14 May } 2017 \\
\text { Available Online: } \\
\text { 10 June } 2017\end{array}$ \\
\hline
\end{tabular}

Agricultural and horticultural applications of sewage sludge are becoming popular as a means of nutrient recycling in many areas of the world (Jacobs, 1981). Guidelines on application of sewage sludge should take account of many factors, such as sludge type, time and method of application (Shepherd, 1996). Because of a growing need to apply municipal sewage sludge on agricultural lands, there is a developing urgency to have criteria for disposal practices that will preserve the productivity of these lands and enhance the productivity and quality of crops (Chaney et al., 1987). The objective of this study, therefore, was to investigate the effect of sewage sludge on growth and yield of marigold (Targets erecta) to combat the scarcity of chemical fertilizers and their negative residual impact on soil physico-chemical properties. Results indicated that sewage sludge can be safely used as a rich organic matter for realizing marigold yield inside of inorganic fertilizers with ecofriendly manners. Among treatments, T5 (100\% sewage sludge) was found to be significantly superior in all observed parameters.

\section{Introduction}

India has a long tradition of floriculture. The commercial activity of production and marketing of floriculture products with low cost technology is a source of gainful agribusiness option and could generate quality employment to scores of people. In India, flowers are cultivated in area of 2.72 lakh ha with annual production of about 16.8 lakh million tonnes during the year 2013, earning 17.7 lakh million rupees by their export (Indian Statistical Data Base, 2013).
Marigold is one of the most important decorative flowers. In several states of India they are grown commercially in fields where they are claimed by some to be more profitable than any other crops. Marigold is even helping to play a vital role as a cash crop to poor farmers in the north of India.

Solid wastes are the organic and inorganic wastes generated by rapid increased production, consumption and other human and animal activities of the urban society, 
normally discarded as useless or unwanted or those which have lost their value to the first user and are a major cause of pollution (Mee and Topping, 1998) In developing countries, increasing waste production accompanies to urbanization (Ahmed and Ali 2004) and the waste produced generally has high moisture content and a low combustible fraction (e.g., paper and cardboard) (Ali 2003) and found to be composed of vegetative matter $(44 \%)$ and inert materials $(42 \%)$ in a developing country like India (Damodaran et al., 2003). Sewage sludge is a residual mixture of organic and inorganic solids derived from municipal waste water treatment. It contains large amount of major and micro nutrients besides having high organic matter content. Hence, it can improve soil physical, chemical and biological properties Singh and Agrawal (2009). Thus, it can be explored as an alternative organic source to supplement chemical fertilizers in crop production. The major interest to use this sewage sludge for growing crops is to promote the concept of wealth out of waste in order to have green and clean Earth. It also makes better earning by investing less as low cost technology.

Waste management has become a major environmental challenge, and land application of sewage sludge is generally considered the best option for disposal of sewage sludge because it offers the possibility of recycling plant nutrients, provides organic material, improves soil fertility along with physical properties and enhances crop yields (Robert $e t$ al., 2011).

\section{Materials and Methods}

\section{Study area}

A pot culture experiment was conducted on alfisols (red soil) at green house farm of the Department of Horticulture, College of Agriculture, Rajendranagar, Hydeabad during kharif 2013 to study the innovative approache of effect of sewage sludge on growth and yield of marigold (Var. Happiness). The sewage sludge for present study was taken from Noor Mohammad Kunta-Sewage Treatment Plant (NMK-STP) which is situated $2.5 \mathrm{~km}$ away from College of Agriculture Rajendranagar, Hyderabad. The experiment was laid out in Completely Randomized Design (CRD) with three replications and necessary data was collected whenever required. There were seven treatments consisting of $\mathrm{T} 1 \quad(20 \%$ sewage sludge), T2 (40\% sewage sludge), T3 (60\% sewage sludge), T4 (80\% sewage sludge), T5 (100\% sewage sludge), T6 (RDF - Inorganic N,P and K@100, 100 and 100 kg ha-1, respectively) and T7 (Control).

Meteorological data including daily precipitation and maximum and minimum temperatures were collected from the observatories located at Agricultural Research Institute (ARI), Rajendranagar, Hyderabad, for the period of July - November, 2015. This period was taken as the reference period.

Height of the plants was recorded by measuring from the base of the stem to the growing tip of the plant with the help of a meter scale. Height was recorded at 30 DAT, 45 DAT and 60 DAT and expressed in centimetres $(\mathrm{cm})$. The total number of primary branches arising from the main stem of each plant were recorded and expressed in number of branches plant-1. Plants above the soil surface were removed at mid stage (45 DAT) and at harvest stage (90 DAT) and were air dried under shade. Later they were dried in hot air oven at $60^{\circ} \mathrm{C}$ till constant weight was obtained. The weights were recorded and expressed in $\mathrm{g}$ plant-1. Chlorophyll content of the intact leaves at 45 DAT and 60 DAT were recorded with a SPAD meter and the readings were expressed in SPAD units. Number of days taken to first bud appearance was computed from the date of transplanting to the date of first bud 
appearance in the each plant and data were recorded. Number of days taken for $50 \%$ flowering was recorded by counting the days from the date of transplanting to till $50 \%$ flowers opened out of total flowers in each plant and the data were recorded. Five flowers were selected randomly from each plant for recoding flower diameter.

The diameter of flowers was measured by taking the maximum breadth across the flower head through using 15 centimetre scale and expressed in centimetres $(\mathrm{cm})$. The fresh weight of individual flower was recorded by weighting of five flowers from each plant. The means were computed and the weight of flowers was expressed in grams flower ${ }^{-1}$. The weight of randomly selected 100 flowers ( $g$ 100-1) recorded as the weight of 100 flowers. The procedure given by Bhaskarachary et al., (1995) was followed for the estimation of total carotene content and expressed in terms of optical density (OD).

Shelf life (days) of flowers were observed using fresh flowers. Total number of flowers was counted from each plant up to harvesting stage and the total number of flowers per plant was recorded. The fresh weight (grams plant $^{-1}$ ) of total flowers per plant was recorded by weighting of total flowers of each plant up to harvesting stage.

\section{Results and Discussion}

Application of sewage sludge significantly increased the plant height of marigold at all growth stages of crop (30, 45 and 60 DAT, Table 1). The plant height was linearly increased with increase in sewage sludge application rates up to $100 \%$ sewage sludge. These finding corroborated by observation made by Mishra et al., (2005).

Significantly maximum number of branches (20.9 per plant, Table 1) in marigold were recorded at 30 DAT in $100 \%$ sewage sludge treatment (T5) followed by $80 \%$ sewage sludge (16.0 per plant) and in contrast the lowest number of branches (6.4 per plant) were recorded in Control (T7). The trend was similar even at 45 and 60 DAT. Sinha et al., (2008) also reported significant increments in growth parameters of two varieties of Vigna radiata at higher rate $\left(30 \mathrm{t} \mathrm{ha}^{-1}\right)$ of sludge amendment.

Application of sewage sludge increased the chlorophyll content (SPAD units, Table 1) of marigold leaves at 45 and 60 DAT with increase in dose of sewage sludge application. The chlorophyll content ranged from 30.5 to 36.0 SPAD units at 45 DAT and 39.4 to 43.8 SPAD units at 60 DAT. Similarly Kanbi and Bhatnagar (2005) reported that chlorophyll content (47.6 SPAD units) in potato was highest with application@ $30 \mathrm{t} \mathrm{ha}^{-1}$ farm yard manure as compared with rest of treatments.

The maximum dry matter (30.2 and $70.6 \mathrm{~g}$ plant $^{-1}$, Table 2) production in marigold was recorded in $100 \%$ sewage sludge treatment (T5) in contrast, lowest value (17.7 and $40.5 \mathrm{~g}$ plant $^{-1}$ ) recorded in Control (T7) at both mid (45 DAT) and harvesting stages (90 DAT) of crop, respectively. Higher availability of nutrients in soil under sewage sludge amendment was the main factor contributing to higher biomass of plants (Singh and Agrawal, 2009).

The striking and interesting feature observed in terms of days to $50 \%$ flowering in marigold was that unlike to the values recorded with respect to earlier mentioned parameters viz., plant height, and number of branches, chlorophyll content and dry matter production. The minimum value for days to $50 \%$ flowering (33.8 DAT, Table 2) was noticed in $80 \%$ sewage sludge treatment (T4) followed by $100 \%$ sewage sludge treatment (35.5 DAT). 
Int.J.Curr.Microbiol.App.Sci (2017) 6(6): 825-831

Table.1 Effect of sewage sludge on plant height, number of branches per plant and chlorophyll content of Marigold

\begin{tabular}{|c|c|c|c|c|c|c|c|c|c|}
\hline \multirow{2}{*}{\multicolumn{2}{|c|}{ Treatments }} & \multicolumn{3}{|c|}{ Plant height $(\mathbf{c m})$} & \multicolumn{3}{|c|}{ Number of branches per plant } & \multicolumn{2}{|c|}{$\begin{array}{c}\text { Chlorophyll content (SPAD } \\
\text { units) }\end{array}$} \\
\hline & & 30 DAT & 45 DAT & 60 DAT & 30 DAT & 45 DAT & 60 DAT & 45 DAT & $60 \mathrm{DAT}$ \\
\hline $\mathbf{T}_{1}$ & $\begin{array}{c}20 \% \text { of sewage } \\
\text { sludge }\end{array}$ & 35.9 & 50.2 & 66.3 & 6.9 & 11.8 & 16.2 & 31.8 & 39.9 \\
\hline $\mathbf{T}_{2}$ & $\begin{array}{c}40 \% \text { of sewage } \\
\text { sludge }\end{array}$ & 39.7 & 54.7 & 70.4 & 7.5 & 12.7 & 20.5 & 33.2 & 40.9 \\
\hline $\mathbf{T}_{3}$ & $\begin{array}{c}60 \% \text { of sewage } \\
\text { sludge }\end{array}$ & 45.6 & 60.7 & 76.5 & 9.7 & 14.8 & 21.8 & 34.1 & 42.1 \\
\hline $\mathbf{T}_{4}$ & $\begin{array}{c}80 \% \text { of sewage } \\
\text { sludge }\end{array}$ & 53.9 & 68.8 & 84.6 & 16.0 & 20.3 & 22.9 & 34.9 & 44.0 \\
\hline $\mathbf{T}_{5}$ & $\begin{array}{c}100 \% \text { of sewage } \\
\text { sludge }\end{array}$ & 62.4 & 77.6 & 93.1 & 20.9 & 23.1 & 25.3 & 36.0 & 43.8 \\
\hline $\mathbf{T}_{6}$ & $\begin{array}{c}\text { RDF } \\
\text { (Recommended } \\
\text { Dose of Fertilizer) }\end{array}$ & 36.7 & 52.8 & 67.1 & 8.6 & 12.2 & 16.7 & 30.9 & 40.7 \\
\hline $\mathbf{T}_{7}$ & Control (Untreated) & 35.1 & 49.7 & 66.0 & 6.4 & 10.9 & 13.6 & 30.5 & 39.4 \\
\hline & $\mathrm{CD}$ & 5.3 & 6.4 & 6.7 & 1.2 & 2.2 & 2.0 & 1.4 & 2.0 \\
\hline & $\mathrm{SE}(\mathrm{d})$ & 2.4 & 3.0 & 3.5 & 0.5 & 1.0 & 0.9 & 0.6 & 0.9 \\
\hline & $\mathrm{SE}(\mathrm{m})$ & 1.7 & 2.1 & 2.5 & 0.4 & 0.7 & 0.6 & 0.4 & 0.6 \\
\hline
\end{tabular}

DAT- Days After Transplanting 
Table.2 Effect of sewage sludge on dry matter production, days to 50\% flowering, number of flowers per plant and Total weight of flowers per plant of Marigold

\begin{tabular}{|c|c|c|c|c|c|c|}
\hline \multicolumn{2}{|r|}{ Treatments } & \multicolumn{2}{|c|}{ Dry matter production $\left(\right.$ g plant $\left.^{-1}\right)$} & \multirow{2}{*}{$\begin{array}{c}\text { Days to } \\
50 \% \\
\text { flowering } \\
\text { (DAT) }\end{array}$} & \multirow{2}{*}{$\begin{array}{c}\begin{array}{c}\text { Number of flowers } \\
\text { per plant }\end{array} \\
\text { Up to harvesting stage }\end{array}$} & \multirow{2}{*}{$\begin{array}{c}\begin{array}{c}\text { Total weight of } \\
\text { flowers per plant }\end{array} \\
\text { Up to harvesting stage }\end{array}$} \\
\hline & & Mid stage & Harvesting stage & & & \\
\hline $\mathbf{T}_{1}$ & $\begin{array}{c}20 \% \text { of sewage } \\
\text { sludge }\end{array}$ & 18.0 & 41.2 & 43.3 & 17.1 & 85.8 \\
\hline $\mathbf{T}_{2}$ & $\begin{array}{c}40 \% \text { of sewage } \\
\text { sludge }\end{array}$ & 19.9 & 45.7 & 41.3 & 23.3 & 119.0 \\
\hline $\mathbf{T}_{3}$ & $\begin{array}{c}60 \% \text { of sewage } \\
\text { sludge }\end{array}$ & 22.7 & 52.5 & 39.5 & 31.9 & 169.4 \\
\hline $\mathbf{T}_{4}$ & $\begin{array}{c}80 \% \text { of sewage } \\
\text { sludge }\end{array}$ & 26.3 & 61.1 & 33.8 & 44.1 & 287.0 \\
\hline $\mathbf{T}_{5}$ & $\begin{array}{c}100 \% \text { of sewage } \\
\text { sludge }\end{array}$ & 30.2 & 70.6 & 35.5 & 51.7 & 305.2 \\
\hline $\mathbf{T}_{6}$ & $\begin{array}{c}\text { RDF } \\
\text { (Recommended } \\
\text { Dose of Fertilizer) }\end{array}$ & 18.7 & 42.9 & 41.9 & 19.7 & 94.7 \\
\hline $\mathbf{T}_{7}$ & Control (Untreated) & 17.7 & 40.5 & 44.3 & 15.0 & 67.6 \\
\hline & $\mathrm{CD}$ & 2.1 & 3.8 & 4.3 & 4.7 & 25.8 \\
\hline & $\mathrm{SE}(\mathrm{d})$ & 1.0 & 1.7 & 1.9 & 2.2 & 11.9 \\
\hline & $\mathrm{SE}(\mathrm{m})$ & 0.7 & 1.2 & 1.4 & 1.5 & 8.4 \\
\hline
\end{tabular}

DAT- Days After Transplanting, Mid stage- 45 DAT, Harvesting stage- 90 DAT 
Begum (2011) was also reported that, application of municipal sewage sludge vermicompost (MSSVC) @ 20 t ha $^{-1}$ significantly increased the plant height, number of fruits per plant and fruit weight of tomato than more dose $\left(30 \mathrm{t} \mathrm{ha}^{-1}\right)$ of MSSVC.

The significantly highest number of flowers (51.7 plant $^{-1}$, Table 2) per plant in marigold were recorded in $100 \%$ sewage sludge treatment (T5) followed by $80 \%$ sewage sludge treatment (44.1 plant $\left.^{-1}\right)$. The lowest number of flowers (15.0 plant $^{-1}$ ) was recorded by the treatment of Control (T7). Akdeniz et al., (2006) opined that, there was significant difference between $\mathrm{N}$ sources viz., sewage sludge and chemical fertilizer in respect to yield, grain weight, grain size and plant height in sorghum.

The total weight of flowers per plant in marigold was linearly increased with increase in sewage sludge application rates. The significantly highest and lowest total weight of flowers (305.2 and $67.6 \mathrm{~g} \mathrm{plant}^{-1}$, Table 2) per plant was observed in treatments of $100 \%$ sewage sludge (T5) and Control (T7), respectively. Singh and Agrawal (2009) reported that significant increments of 75 and $135 \%$ in yield of lady's finger applied with 1.26 and $2.51 \mathrm{~kg} \mathrm{~m}^{-2}$ sewage sludge amended.

In conclusion, the disposal of sludge by incineration, land filling and ocean dumping can present serious environmental problems. Land application of sludge is the best recycling option.

Organic waste application to sandy soil can help restore its agricultural productivity (Hornick and Parr, 1987) and produce better yields (Epstein et al., 1976). Growth parameters viz., plant height, number of branches, chlorophyll contents, dry matter production and number flowers per plant in marigold were significantly highest in $100 \%$ sewage sludge treatment (T5).

\section{Recommendations}

The present study focused on horticulture crop (marigold), and based on the batter results along with concept of wealth out of waste it is conclude that, the sewage sludge is also useful for agricultural as well as vegetable crops.

\section{Acknowledgements}

We wish to acknowledge the help and support received from Dept. of Environmental Science and Technology, College of Agriculture, Acharya N.G. Ranga Agricultural University, Rajendranagar, Hyderabad-500030, during the experimental work. This paper is a part of the M.Sc. thesis of the first author, Praveen solanki, who carried out most of the field work and laboratory analysis. Baby Akula, D. Jagdishwar Reddy and S. Harish Kumar Sharma helped in writing and statistical analysis of data.

\section{References}

Ahmed, S.A. and Ali, M. 2004. Partnerships for solid waste management in developing countries: linking theories to realities. Habitat Int., 28: 467-479.

Ali, A. 2003 Waste management-developing world and countries in transit. In: Christensen TH, Cossu R, Stegmann R (eds) Proceedings of Sardinia 2003, 9th international waste management and landfill symposium. S. Margherita di Pula, Cagliari, Italy.

Akdeniz, H., Yilmaz, I., Bozkurt, M.A. and Keskin, B. 2006. The effect of sewage sludge and nitrogen applications on grain sorghum grown (Sorghum vulgare L.) in van-Turkey. Polish J. Environ. Studies, 15(1): 19-26.

Begum, A. 2011. Evaluation on municipal sewage sludge vermicompost on two 
cultivars of tomato (Lycopersicon esculentum L.) plants. Int. J. Chem. Technol. Res., 3(3): 1184-1188.

Bhaskarachary, K., Rao, D.S.S., Deosthale, Y.G. and Reddy Ninodini. 1995. Carotene content of some lemon and less familiar foods of plant origin. Food Chem., 55: 189-193.

Chaney, R.L., Bruins, R.J.F., Korcak, R.F. and Cole, D. 1987. Transfer of sludgeapplied trace elements to the food chain. In page AL (ed) land application of sludge, Lewis Publishers, Chelsea, Michigan, pp 67-99.

Damodaran, N., Robinson, A., David, E. and Kalas, A.N. 2003. Urban solid waste generation and management in India. In: Christensen TH, Cossu R, Stegmann R (eds) Proceedings of Sardinia 2003, 9th international waste management and landfill symposium, S. Margherita di Pula, Cagliari, Italy.

Epstein, E., Taylor, J.M. and Chaney, R.L. 1976. Effects of biosolids and sludge compost applied to soil on some soil physical and chemical properties. $J$. Environ. Qual., 5: 422-426.

Hornick, S.B. and Parr, J.F. 1987. Restoring the productivity of marginal soils with organic amendments. Am. J. Altern. Agric., 11(2): 64-68.

Indian Statistical Data Base. 2013. www.In diastat.com/table/agriculture/2/totalflow ers/17462/381147/data.aspx.

Jacobs, L.W. 1981. Agricultural application of sewage sludge. In: Borchardt JA (Ed) Sludge and its ultimate disposal, Ann Arbor Science Publishers, Michigan, pp 109-125.

Kanbi, V.H. and R. Bhatnagar. 2005. Effect of organic and inorganic fertilizer on yield, chlorophyll content, dry matter and keeping quality of potato. Potato J., 32: $161-62$.

Mee, D.L. and Topping, G. 1998. Black Sea pollution assessment. In: GEF Black Sea environmental programme. Black Sea environmental series, Vol. 10. UN Publications.

Mishra, R.K., Singh, G. and Chaurasia, S.N.S. 2005. Effect of sources of nutrients on performance of okra (Abelmoschus esculentus (L.) Moench). Sri Lankan J. Agri. Sci., 42: 52-57.

Robert Edwin White, Silvana, I., Torri and Rodrigo Studart Correa. 2011. Biosolids Soil Application: Agronomic and Environmental Implications. Hindawi Publishing Corporation. Appl. Environ. Soil Sci., Vol. 2011, 3 Pp. doi:10.1155/2011/928973.

Shepherd, M.A. 1996. Factors affecting nitrate leaching from sewage sludges applied to a sandy soil in arable agriculture. Agric. Ecosyst. Environ., 58: 171-185.

Singh, R.P. and Agrawal, M. 2009. Use of sewage sludge as fertilizer supplement for Abelmoschus esculentus plants: physiological, biochemical and growth responses. Int. J. Environ. Waste Manage., 3: 91-106.

Sinha, S., Singh, S. and Mallick, S. 2008. Comparative growth response of two varieties of Vigna radiata L. (var. PDM 54 and var. NM 1) grown on different tannery sludge applications: effects of treated wastewater and ground water used for irrigation. Environ. Geochem. Health, 30(5):

\section{How to cite this article:}

Praveen Solanki, Bhavya Kalavagadda, Baby Akula, S. Harish Kumar Sharma and Jagdishwar Reddy, D. 2017. Effect of Sewage Sludge on Marigold (Tagetes erecta). Int.J.Curr.Microbiol.App.Sci. 6(6): 825-831. doi: https://doi.org/10.20546/ijcmas.2017.606.097 